See discussions, stats, and author profiles for this publication at: https://www.researchgate.net/publication/320825128

Instructing and Mentoring Ex-Con University Students in Departments of Criminology and Criminal Justice

Article $\cdot$ November 2017

DOI: 10.1080/23774657.2017.1387081

CITATIONS

6

2 authors, including:

Jeffrey lan Ross

University of Baltimore

149 PUBLICATIONS 1,296 CITATIONS

SEE PROFILE

Some of the authors of this publication are also working on these related projects:

Project Violence View project

Project Convict Criminology View project
READS

261 


\section{Instructing and Mentoring Ex-Con University Students in Departments of Criminology and Criminal Justice}

\section{Richard Tewksbury \& Jeffrey lan Ross}

To cite this article: Richard Tewksbury \& Jeffrey lan Ross (2017): Instructing and Mentoring ExCon University Students in Departments of Criminology and Criminal Justice, Corrections

To link to this article: http://dx.doi.org/10.1080/23774657.2017.1387081

曲 Published online: 02 Nov 2017.

Submit your article to this journal $\pi$

Q View related articles $\longleftarrow$

View Crossmark data \lceil 


\title{
Instructing and Mentoring Ex-Con University Students in Departments of Criminology and Criminal Justice
}

\author{
Richard Tewksbury and Jeffrey lan Ross ${ }^{\mathrm{b}, \mathrm{c}}$ \\ aDepartment of Criminal Justice, University of Louisville, Louisville, Kentucky USA; ${ }^{b}$ School of Criminal Justice, \\ University of Baltimore, Baltimore, Maryland USA; 'Criminology, Criminal Policy and Police Science, Ruhr \\ University, Bochum, Germany
}

\begin{abstract}
Recognizing the growing presence of university students who are also ex-cons, this article discusses the challenges of working with such individuals and offers practical suggestions for ways to enhance such interactions. The effects of institutional socialization, cultural differences, and a range of abilities and motivations presented by excon students requires a need to design and implement unique instructional, especially mentoring, approaches that are most likely to be successful.
\end{abstract}

\section{KEYWORDS}

Mentoring; prisoner re-entry; instruction

\section{Introduction}

Since the invention of the penitentiary, it has been assumed that along with the punishment that they receive, inmates ${ }^{1}$ should be rehabilitated. Over the 200 -plus years of experimentation with institution-based education and job training programs, it has been posited and supported that much can be gained when the prisoner is released and pursues formal education, particularly at a college or university (Holzer, Raphael, \& Stoll, 2003; Maruna, 2001; Maruna, Immarigeon, \& LeBel, 2004). ${ }^{2}$ However, this process is not as easy as it sounds. There are numerous hurdles that ex-offenders incur in their efforts to earn a postsecondary education, and there are challenges for university-based instructors and administrators.

Why is this important? Although not a sizeable population in American universities (due to a multiplicity of factors), there are an increasing number of individuals who are being released from jails and prisons in the United States and elsewhere. A portion of them will find employment, others will be reincarcerated, and a minority will enter our colleges and universities. Less understood are the persons who are responsible and/or who volunteer to guide and/or mentor them in their efforts to earn a degree. This mentoring involves a number of challenges for the ex-con and the instructor/professor.

One of the important organizational pillars of convict criminology (Ross \& Richards, 2003) is the importance placed on mentoring convicts and ex-cons. To date this is probably one of the least tended to aspects of this school, movement, and network (Newbold \& Ross, 2013). There is no reliable reason or explanation for why this has occurred, but there is some agreement among individuals who are "members" of the 
convict criminology network that mentoring is still an important aspect and should be encouraged (Ross, Darke, Aresti, Newbold, \& Earle, 2014).

Earning an undergraduate, no less a graduate, degree can be an alienating, confusing, and highly stressful experience for any student. Many institutions of higher learning recognize this challenge, and that is why they offer workshops, develop units, and/or employ resource personnel to assist students who may need some guidance in this matter. Some colleges and universities in the United States, for example, cater to distinct races/ ethnicities or genders. For example, there is a long tradition of Historically Black Colleges and Universities (HBCUs), a system of American Indian Tribal Colleges, and colleges for women that exist. The argument/assumption here is that going to an institution of higher education, with others like oneself, would shield students from the disruptive effects of racism or sexism and/or that learning in these kinds of environments will take the pinch or sting out of the alienation of the college experience. Likewise colleges may have programs for military Veterans to assist them in negotiating the new experience. Unfortunately, few measures exist that assist and/or monitor the environment of college campuses to determine how friendly they are for formerly incarcerated students.

In many respects the transition of the ex-con to the university classroom may share similarities with others who have important life experiences (the mother, the Veteran who has come back from a tour of duty, and/or a senior coming back to school). In this regard, the work of university faculty and administrators with formerly incarcerated students has many/all of the characteristics and challenges associated with working with any nontraditional student, as well as some very specific and unique aspects that arise directly from the label and experience of being an ex-con. Although these challenges are real and can be sizeable, they are by no means insurmountable. What is required for formerly incarcerated students pursuing a degree and the faculty that chooses to work with them is to refocus expectations, become culturally competent, and to recognize the different psychological, social, and educational backgrounds that such students bring with them to campus.

Keep in mind that many instructors and professors may wish to assist ex-cons but lack the training, knowledge, and/or disposition to do so effectively. This article is an attempt to provide some best practices to assist this effort. Our discussion and suggestions are based on a review of the scholarly literature and the authors' experiences working as professors for a combined nearly five decades of teaching in criminology/criminal justice departments at universities in the United States. Both have also worked inside correctional facilities.

\section{Literature review}

There is a rich but uneven literature on mentoring in academia. Styles of mentoring, experiences of both doing and receiving mentoring and tips, guidelines, and suggestions on how to mentor students are rife in the social sciences, including criminal justice, literature (Kim, Stallings, Merlo, \& Wan-Chun Lin, 2015; Kunselman, Hensley, \& Tewksbury, 2003; Ragins, Cotton \& Miller, 2000). There is also no shortage of articles and books offering advice to inmates who are seeking post-high school education (e.g., Michaels, 2011; Ross \& Richards, 2009; Taylor \& Schwartzkopf, 2013; Zoukis, 2012). One interesting omission in the scholarly literature is a discussion of how mentoring can and should function when mentees are ex-cons. Although there is scholarship available about 
how formerly incarcerated students can be mentors to individuals who are recently released from prison (Kavanagh \& Borrill, 2013), the idea of mentoring for ex-cons has been essentially ignored.

Despite strong support in the literature for higher education as a tool of rehabilitation (Hall, 2015; Kim \& Clark, 2013; Steurer, Smith, \& Tracy, 2001), the means by which such a population who is disenfranchised, with low social capital, yet high in needs can be integrated to academic environments has been neglected. This is interesting because it is well recognized that education in correctional settings ("correctional education") is significantly different than traditional education in regards to practices, models, theories and structure. Yet, seemingly, when students leave the confines of a jail or prison, they are assumed to be no different in their approaches and needs than traditional students. This is clearly an oversight on the part of educators, and one that is important to address.

Although a fledgling literature exists on professors working with convicts on research studies (e.g., Ross, Zaldivar, \& Tewksbury, 2015; Taylor \& Tewksbury, 1995), and the receptivity (hiring practices) of academic departments for professors with criminal pasts (Ross et al., 2011), there is a lack of scholarship examining the experiences of ex-con students on college campuses, as this population seems to only be addressed when a formerly incarcerated student is discovered among the student population or when a "problem" arises. However, the limited work that is available on this topic suggests that ex-con students often find their campuses as a "refuge" from stresses and challenges in their lives (Tewksbury, 2013). Other studies have taken a different perspective and instead of focusing on how formerly incarcerated students perceive their on-campus experiences, the campus and its policies have been the focus. Here, the literature suggests that:

applicants with criminal records potentially face intrusive background inquiries that make application more challenging, whether or not ex-offenders have equitable access to criminology and criminal justice doctoral programs remains rather nebulous. By way of the exoffender identification process, many universities and programs appear reluctant to offer access to prospective students with criminal records. (Connor \& Tewksbury, 2012, p. 337)

Although this situation applies explicitly to doctoral programs of study in criminal justice/criminology, it is a strong indicator that even in a discipline that arguably is the most informed on ex-cons' abilities and social challenges, the degree of "friendliness" and equal-access opportunities are substantially reduced. Specifically, although few programs have explicitly stated prohibitions on formerly incarcerated students, fully one half of criminal justice/criminology programs do require applicants to pass a criminal background check prior to being admitted (Connor \& Tewksbury, 2012).

For those ex-cons that do navigate their way on to campus and through a doctorate program, opportunities are available, but often only with restrictions and only very selectively (Ross et al., 2011). In simple terms, it is not easy. Pursuing an academic position with a criminal record is significantly more difficult and significantly less likely to end successfully. Criminal background checks are standard practice on nearly all campuses and institutional policies frequently prohibit hiring of individuals with a criminal record (Connor \& Tewksbury, 2012).

What is necessary to round out the situation and promote the best opportunities for rehabilitation and success in mainstream life for ex-cons is some type of guide and appropriate practical advice that will assist departmental and university faculty and 
administrators in providing this manner of education. Higher education is largely without a culture or foundation upon which to build educational endeavors that foster the positive transition and growth of inmates who elect to enroll in postsecondary studies. To do this, the current authors have consulted the written scholarly and popular literature and draw upon their experiences mentoring formerly incarcerated students through the educational process. Our experience mainly comes from working in departments/schools of criminology/criminal justice and is specific to this environment, thus caution is advised for those seeking to extend our advice to other disciplines.

The suggestions that follows is primarily aimed at faculty (and college and university administrators) interested in (or simply compelled to) working with this special class of students. As a by-product, this information should also be of assistance to ex-con students. As such the suggestions we offer is focused on the perspectives and experiences of each audience, though many of the issues that are addressed herein are shared by both groups, just experienced or approached in different manners.

\section{Recommendations for successful mentoring of ex-con students}

Working with ex-cons, whether as undergraduate or graduate students, presents a unique set of obstacles that while not wholly unique to this class of student are often intense and potentially insurmountable obstacles, unless such are anticipated and solutions are known. The challenges of formerly incarcerated students arise from their experiences as inmates and their more global background and life experiences. As such, the ways that college and university-level instructors can effectively mentor such students need to be attuned to the effects that incarceration has on individuals (and loved ones) as well as recognizing that these individuals may need different, perhaps more intensive and skillful, attention and guidance than students with whom we are typically most familiar. The remainder of this section addresses some of the ways that the special challenges presented by ex-con students can be effectively addressed, and perhaps even how to transform the challenges to advantages.

\section{Recognize the trauma instilled by incarceration}

Life in prison is not pleasant for most inmates. Many aspects of incarceration may remain with individuals long after release. American correctional institutions are unique environments. Those who wish to survive this setting must pay attention to different cues and triggers to minimize harm. In the prison yard and on the tiers convicts adopt the convict code where there are norms that they must adhere to if they are going to survive and do their own time (Irwin \& Cressy, 1962). As some mentors of ex-con students recognize, some of the common ways we interact with other students-including our words (formal and slang), our actions (including our unconscious gestures, touching, movements, and minute actions), and even our looks (the way we or others look at them) can be reminiscent of traumatic incarceration experiences. Some formerly incarcerated students suffer from posttraumatic stress disorder (PTSD) (Murphy, 2012) and have "flashbacks" to unanticipated stimuli. And even for those who do not suffer from these extreme behaviors, there are likely to be small, unanticipated, often seemingly innocuous words, actions, and looks that psychologically transport an ex-con back to prison, and can have significant 
emotional, mental/psychological and interactional effects. As a mentor, it is important to not only be aware of how your own words and actions may be interpreted, but so too should you work with the formerly incarcerated students you supervise, to be cognizant of their sensitivities and to strive to find ways to effectively manage them.

\section{Respect the limitations imposed by supervision}

For ex-con students who are still on active supervision (i.e., probation or parole), know that there are restrictions on their time, activities, movement and access to resources that are not present for other students. For those students with conditions of supervision, and especially for sex offenders (on and off supervision), some restrictions are going to be present and need to be accommodated. Curfews, travel restrictions, Internet access, presence around particular types of people, and mandatory weekly meetings with probation/parole officers, treatment providers and others are all common for ex-cons, and must be prioritized over school work and expectations imposed by mentors. These are legal requirements that they need to take care of first (before school work). Failure to conform may result in further sanctions including reincarceration. Formerly incarcerated students may also be denied fellowships and/or housing because of the nature of the crimes for which they were convicted (Connor \& Tewksbury, 2012; Oliver, 2010; Tewksbury \& Lees, 2006). These sorts of personal challenges may bleed into and seriously influence ex-con students' work, classroom attendance, and behavior and even the student/mentor relationship. Regardless of the steps taken by mentors and ex-con mentees, the authority of the state will always supersede academic "rules," deadlines, and expectations.

\section{Structure is familiar}

Incarceration is founded on a structured environment, and those who live and work within such a setting are acutely accustomed to being bound by the formal and informal rules of the carceral institution. When working with an ex-con student, recognize this fact, and use it to your collaborative advantage. Whereas many of today's traditional students are most accustomed to lack of structure and exceptions for just about anything, those who have done time in jail or prison have been socialized to follow a schedule and to have their time highly structured. As a mentor, use this familiarity to your advantage-have deadlines, have explicit expectations, work on a schedule. Such approaches are well known to be advantageous, and when working with a student that knows, expects and perhaps even wants structure to their activities and lives, this can be a great advantage.

\section{Basic skills may need attention}

Although many ex-cons are highly intelligent, motivated, and more than willing to put in the time and effort to succeed academically, many have substantial deficits in their basic academic skills. Many formerly incarcerated students come from a background where academic skills were not emphasized or secondary (or worse) in terms of their value to the family unit, they attended poor schools, may have been educated inside correctional facilities or at the very least have simply not done much reading, writing, math, or analytic thinking in quite some time. Incarceration typically quashes intellectual pursuits and stymies efforts to improve oneself. As 
such, when seeking to advance academically on the outside, the basic skills (reading, spelling, basic math, understanding how and where to find information, etc.) may be severely lacking. As a mentor it is incumbent on faculty to recognize this possibility and to assess a student's abilities, as well as providing means to enhance the skills that may be lacking or long unused.

\section{Harness the enthusiasm}

For those ex-cons who leave jail and prison and embark on a new path, whether that be a new relationship, a new job or academics, it is common for there to be an enthusiasm and drive to "do it, and do it now!" Academic pursuits, however, are notoriously slow and long term. Hence, if a formerly incarcerated student comes to academia with enthusiasm, energy, and a desire to immediately complete a degree, it is important to temper that enthusiasm with realistic expectations yet not to discourage the student to the point of having this path be yet another one that leads to failure and frustration. Working with enthusiastic students provides an opportunity to push students for more, yet it also is a time to provide focus on the short-term and long-term advantages and gains that can come from academic pursuits. As a mentor, use the enthusiasm, build on it, encourage it, but also frame it with realistic plans and goals. Yes, a student with enthusiasm for learning and achieving is a great (and not often encountered) resource; yet beware of the adage that "too much of a good thing is not necessarily a good thing."

\section{Managing expectations}

Some of the challenges for instructors and formerly incarcerated students are assisting them to keep their expectations in check. Many convicts and ex-cons, like some criminal justice practitioners (or former practitioners) in the classroom, think that they have a monopoly on knowledge in particular, especially as it pertains to the carceral experience. It is important to temper this enthusiasm to deal with the exegeses of the academic profession that is slower and more deliberative than the ways of carceral institutions.

Realize "professors" may be put on a pedestal. In our experiences convicts and to a lesser degree ex-cons often hold stereotypical (if not romantic) views of professors, including the scope of their knowledge and capabilities. As individuals largely unexposed to the realities of higher education, many believe that the full scope of an academic's work is "just" to do research or teach. Many formerly incarcerated students also (sadly and incorrectly) believe that because of the status of one as a "doctor" that policy makers actively seek out, listen and adhere to our insights and advice. Academics may also be assumed to have unlimited resources available, and a plethora of support for assistance/assistants. Knowing that such students have unrealistic views and expectations for what a professor can do is important so as to temper their expectations and assist such students to approach their studies in a realistic manner.

Identity management may be necessary. For some ex-con students there is likely to be a strong need to actively manage their identity and sort out if, when, how, to whom, and under what conditions to disclose their status as a formerly incarcerated person. In simple terms, being an ex-con is stigmatizing, and ex-cons know this. After release from prison the many 
challenges faced by offenders-including finding housing, a job, friends, and basic social interactions may be colored by the label of "ex-con." Some people will not respond well to individuals with such a label, and managing where, when and how this portion of one's identity is shared is important. So too may one's identity management influence the relationship with a mentor. Simple things like the language one uses-is the student an "ex-con," a "convict," an "offender," a "burglar," a "prisoner," or some other label? How does one respond to such language? What is acceptable and nonstigmatizing? Such decisions are probably best left to the individual student, but need to be recognized and respected by mentors.

Stigma can be a courtesy as well. Courtesy stigma (Goffman, 1963) is the idea that negative perceptions and labeling extend not only to the discredited or discreditable individual, but also to those closely aligned or associated with the stigmatized. Mentors who elect to work with formerly incarcerated students are likely to be granted courtesy stigmas by colleagues, other students, and members of one's social world who learn of the association with an ex-con. Just as scholars who study "odd" or "socially unacceptable" topics may be stigmatized (see Tewksbury, 2004, 2015), so too are those who actively (and openly) work with socially undesirable students labeled by their colleagues, students, and academic administrators and consequently apt to suffer the formal and informal indignities that accompany stigmatization.

Be aware of the "isms". Prisons are well known for their lack of egalitarian social structure. Forms of prejudice and discrimination are omnipresent in correctional facilities, and encompass all forms of prejudicial views-sexism, racism, classism, homophobia, xenophobia, and many others. The presence of these discriminatory beliefs (and the practices they produce) not only shape the day-to-day culture, structure and actions of correctional institutions, but so too do they indoctrinate inmates and change their views (Jones \& Schmid, 2000). As such, mentors should expect there to be, at the very least, some traces of prejudicial and discriminatory views held by ex-con students. Such approaches are antithetical to contemporary academic dogma, and when realized are likely to cause problems (interpersonal and academic) for ex-con students. Mentors can, and should, be on guard for such views to emerge, and need to work with formerly incarcerated students to minimize and negate the presence and consequences of such consequences of incarceration.

The need for finishing school. Not only are correctional facilities hotbeds for prejudice and discrimination, but so too are jails and prisons; places where manners, courtesy, decency, and politeness are often viewed as liabilities rather than assets. In the academic world, we expect others to be courteous, polite, accepting of others (and their views), and more or less refined and sophisticated. In prison inmates are immersed in a world of harshness and over the top masculinity (Sabo, Kupers, \& London, 2001). Hence, many ex-con students may be likely to bring their social dispositions with them to campus. Whereas a statement such as "god damn it, move motherfucker!" may be a normal, unnoticed way of speaking in prison, such a statement in the halls of academia will undoubtedly be met with shock, repulsion, and stigmatizing reactions. The point is formerly incarcerated students are likely to be lacking in social graces. They may use much rougher and cruder language than typical academic jargon. Ex-con students may present in a much gruffer, hardened, aggressive manner than that to which mentors are accustomed. 
Not only will language and demeanor need to be adjusted, but appearances require modification too. If your mentee has fallen prey to copious tattoos, likes to pump iron on a continuous basis, and goes out for numerous smoke breaks, you may have to politely school him in the norms of the academic world where these behaviors and traits are largely frowned upon.

In the more genteel world of academia convicts must now interact with professors, students and administrators-constituents for whom "prison language" and appearance is likely to be inappropriate, offensive, and threatening. Especially in criminology/criminal justice programs, despite the wide variability in topical, pragmatic orientation (theoretical and research driven or "cop shops" focused on preparing students for careers in criminal justice), many students and instructors are likely to have had negative experiences with criminals, convicts, and ex-cons. In other words, it is not unexpected that many students and instructors may hold "anticriminal" biases. Hence, it would not be uncommon for an ex-con student to encounter stigma, rejection, and ostracization in such setting. This is by no means a necessity, however, as sensitivities, understandings and skills can readily be developed. This is well illustrated by students and instructors in Inside Out programs, such as that run out of Temple University, and the Inviting Convicts to College program run by instructors and professors out of the Department of Criminal Justice at University of Wisconsin, Oshkosh that has instructors teach in local correctional facilities (Richards, Rose, \& Reed, 2006). To say that criminal justice instructors do not have biases would be quite naïve. However, with focus and a bit of reorientation, even many initially skeptical and biased instructors can develop into an effective mentor for an ex-con student.

Running interference. Finally, part of the work that instructors who mentor excon students will inevitably include educating fellow faculty and administrators on the ways of the prison and effects that it may have on ex-con students. There may be minor incidents that you hear about through the grapevine, that your fellow instructors find "weird" and or unsettling, and you may be called upon or feel compelled to discuss, and/ or deescalate these situations so that your student walks away relatively unscathed. Mentoring a formerly incarcerated student involves more than just the mentor and the student, so too does it draw in the other faculty, students, and members of the academic community with which the student and mentor have exposure and interactions.

\section{Conclusion}

Criminal offenders are sentenced by courts for purposes of removing them from ongoing criminal opportunities and (supposedly) for purposes of rehabilitation. Although the rehabilitative successes of the criminal justice system are debatable, the one form of programming that has consistently been shown to be effective is academic education. For most offenders, however, education beyond a Graduate Equivalency Diploma will need to be pursued once released from incarceration. College and university campuses and faculty, however, are often unaccustomed or unprepared for working with such students.

The suggestions that we offer here are those that we have discovered-often unintentionally and unpleasantly-through our own work with ex-con students. Our goal herein is to educate and sensitize instructors working with this special population to the somewhat unique challenges that formerly incarcerated students may present and to offer means of successfully addressing these challenges. This needs to be tempered, however, 
with the knowledge that no two ex-cons are the same, and what technique works with one may not work equally as well with another. However, being aware of the fact that there are likely to be differences with and among ex-con students is critical for achieving success with such students. Working with students who are motivated, enthusiastic, serious, but yet perhaps a bit behind in basic skills can be highly rewarding, if one is ready, willing and able to rise to the challenge.

\section{Notes}

1. The words inmate, convict, and prisoner are used interchangeably in this article.

2. The researchers conflate the terms college and university together. The reader should recognize that college here refers to liberal arts colleges and not traditional 2-year colleges that offer diplomas and not degrees.

\section{Disclosure statement}

The authors report no conflicts of interest. The authors alone are responsible for the content and writing of the article.

\section{References}

Connor, D. P., \& Tewksbury, R. (2012). Ex-offenders and educational equal access: Doctoral programs in criminology and criminal justice. Critical Criminology, 20(3), 327-340. doi:10.1007/s10612-011-9142-Z

Goffman, E. (1963). Stigma: Notes on the management of spoiled identity. Englewood Cliffs, NJ: Prentice Hall.

Hall, L. (2015). Correctional education and recidivism: A tool for reduction. Journal of Correctional Education, 66(2), 4-29.

Holzer, H. J., Raphael, S., \& Stoll, M. A. (2003). Employment barriers facing ex-offenders. In Employment dimensions of re-entry: Understanding the nexus between prisoner re-entry and work. Paper presented at the urban institute reentry round table, May 19-20, 2003, New York: University Law School.

Irwin, J., \& Cressy, D. (1962). Thieves, convicts and inmate culture. Social Problems, 10(1), 142-155. doi:10.2307/799047

Jones, R. S., \& Schmid, T. J. (2000). Doing time: Prison experience and identity. Stamford, CT: JAI Press.

Kavanagh, L., \& Borrill, J. (2013). Exploring the experiences of ex-offender mentors. Probation Journal, 60(4), 400-414. doi:10.1177/0264550513502247

Kim, B., Stallings, R. P., Merlo, A. V., \& Wan-Chun Lin, A. (2015). Mentoring in criminology and criminal justice doctoral education: Doctoral program coordinators' perspectives. Journal of Criminal Justice Education, 26(4), 390-407. doi:10.1080/10511253.2015.1049630

Kim, R. H., \& Clark, D. (2013). The effect of prison based college education programs on recidivism: A propensity score matching approach. Journal of Criminal Justice, 41(1), 196-204. doi:10.1016/j.jcrimjus.2013.03.001

Kunselman, J., Hensley, C., \& Tewksbury, R. (2003). Mentoring in academe: Models for facilitating academic development. Journal of Criminal Justice Education, 14(1), 17-35. doi:10.1080/ 10511250300085631

Maruna, S. (2001). Making good: How ex-convicts reform and rebuild their lives. Washington, DC: American Psychological Association. 
Maruna, S., Immarigeon, R., \& LeBel, T. P. (2004). Ex-offender reintegration: Theory and practice. In S. Maruna,R. Immarigeon (Eds.), After crime and punishments: Pathways to offender reintegration (pp. 3-26). Cullompton, England: Willan Publishing.

Michaels, B. C. (2011). College in prison: Information and resources for incarcerated students. Bloomington, IN: Trafford Publishing.

Murphy, D. (2012). Corrections and post-traumatic stress symptoms. Durham, NC: Carolina Academic Press.

Newbold, G., \& Ross, J. I. (2013). Convict criminology at the crossroads: A research note. Prison Journal, 93(1), 3-10. doi:10.1177/0032885512467307

Oliver, B. E. (2010). My sentence is over but will my punishment ever end. Dialectical Anthropology, 34(4), 447-451. doi:10.1007/s10624-010-9165-y

Ragins, B. R., Cotton, J. L., \& Miller, J. S. (2000). Marginal mentoring: The effects of type of mentor, quality of relationship, and program design on work and career attitudes. Academy of Management Journal, 43, 1177-1194. doi:10.2307/1556344

Richards, S. C., Rose, C. D., \& Reed, S. O. (2006). Inviting convicts to college: Prison and university partnership. In The state of corrections: (2005) Proceedings of the ACA annual conferences (pp. 171-180). Lanham, MD: American Correctional Association.

Ross, J. I., Darke, S., Aresti, A., Newbold, G., \& Earle, R. (2014). Developing convict criminology beyond North America. International Criminal Justice Review, 24(2), 121-133. doi:10.1177/ 1057567714531484

Ross, J. I., \& Richards, S. C. (2003). Convict criminology. Belmont, CA: Wadsworth Publishing.

Ross, J. I., \& Richards, S. C. (2009). Beyond bars: Rejoining society after prison. Indianapolis, IN: Alpha Books.

Ross, J. I., Richards, S. C., Newbold, G., Jones, R. S., Lenza, M., Murphy, D. S., \& Curry, G. D. (2011). Knocking on the ivory tower's door: The experience of ex-convicts applying for tenuretrack university positions. Journal of Criminal Justice Education, 22(2), 267-285. doi:10.1080/ 10511251003778982

Ross, J. I., Zaldivar, M., \& Tewksbury, R. (2015). Breaking out of prison and into print? Rationales and strategies to assist educated convicts conduct scholarly research and writing behind bars. Critical Criminology: An International Journal, 23(1), 73-83. doi:10.1007/s10612014-9248-1

Sabo, D. F., Kupers, T. A., \& London, W. J. (Eds.). (2001). Prison masculinities. Philadelphia, PA: Temple University Press.

Steurer, S., Smith, L., \& Tracy, A. (2001). Three state recidivism study. Washington, DC: U.S. Department of Education, Office of Correctional Education.

Taylor, J. M., \& Schwartzkopf, S. (2013). Prisoners' guerilla handbook to correspondence programs in the United States and Canada (3rd ed.). Lake Worth, FL: Prison Legal News.

Taylor, J. M., \& Tewksbury, R. (1995). From the inside out and outside in: Team research in the correctional setting. Journal of Contemporary Criminal Justice, 11(2), 119-136. doi:10.1177/ 104398629501100204

Tewksbury, R. (2004). The intellectual legacy of Laud Humphreys: His impact on research and thinking about men's public sexual encounters. International Journal of Sociology and Social Policy, 24(3/4/5), 32-57. doi:10.1108/01443330410790867

Tewksbury, R. (2013). Sex offenders and campus based sex offender registration: Stigma, vulnerability, isolation and the classroom as refuge. Journal of Qualitative Criminal Justice and Criminology, 1(1), 221-242.

Tewksbury, R. (2015). Using qualitative methods to study sex crimes. In J. M. Miller \& H. Copes (Eds.), Handbook of qualitative criminology (pp. 201-214). London, England: Routledge.

Tewksbury, R., \& Lees, M. B. (2006). Sex offenders on campus: An examination of university-based sex offender registries and the collateral consequences of registration. Federal Probation, 70(3), $50-56$.

Zoukis, C. (2012). Education behind bars: A win-win strategy for maximum security. Camp Hill, PA: Sunbury Publishing. 